\title{
Comparison between audiovisual media and simulation on the toothbrushing skills of elementary school students
}

\author{
Azlina Nuur Sanjaya ${ }^{*}$, Anne Agustina Suwargiani ${ }^{1}$, Riana Wardani $^{1}$ \\ 1'Department of Dental Public Health, Faculty of Dentistry Universitas Padjadjaran, Indonesia
}

\begin{abstract}
Introduction: Oral health education aims to enable an individual to maintain oral health, one of which is tooth brushing. Education media can determine its success. As the development of technology, audiovisual media is also developing. Audiovisual media are commonly used nowadays for educational purpose in many fields, and simulation media in many forms are often used for education. The purpose of this study was to compare the effectiveness of audiovisual media in the form of animated film and simulation media in the form of a dental model on toothbrushing skills. Methods: Quasi-experimental that tend to comparative analytics was conducted with the sample that was taken by purposive sampling technique. Forty students of Ciganitri 2 State Elementary School (SDN Ciganitri 2) aged 12-year old participated in this study. The students were divided into two groups; the first group received an education with an animated film, and the second group received an education with dental models. Measurement of the students' toothbrushing skills performed with pre-test and post-test. All data calculated by independent $\mathrm{t}$-test in each group. Results: The film group and the study model group intervention have equal effectiveness. The paired t-test between the two groups resulted in no significant difference between the effectiveness of audiovisual media and simulation media on the students' toothbrushing skills. Conclusion: Audiovisual media and simulation media group intervention effectively improve toothbrushing skills.
\end{abstract}

Keywords: Audiovisual media, simulation media, toothbrushing skill.

P-ISSN 1979-0201, e-ISSN 2549-6212; Available from: http://jurnal.unpad.ac.id/pjd/article/view/22862

DOI: $10.24198 /$ pjd.vol31no3.22862

Submission: Jul 13, 2019; Accepted: Nov 20, 2019; Published online: Nov 30, 2019

\section{INTRODUCTION}

Dental health education is an activity to convey a message regarding oral and dental health to the community, group, or individual. The ultimate goal of this education is the changing of knowledge and behaviour. ${ }^{1}$ Educational media on education is useful to help learners to understand new things. Level of learning media effectiveness, according to Edgar Dale1, has made for supporting oral health education.

Simulation media is an imitation of the real situations that are designed as close as possible to the actual events, such as dental models. ${ }^{2}$ Film

"Corresponding author: Azlina Nuur Sanjaya, Department of Dental Public Health, Faculty of Dentistry Universitas Padjajaran, Indonesia. Sekeloa Selatan No. 1, Bandung, Indonesia, 40132. Phone: +6281220458511; Email: azlinanuursanjaya@gmail. com 
or audiovisual media is a combination of moving images and sound recordings. Haryoko ${ }^{3}$ stated that technology-based audiovisual learning can be used as an alternative facility in optimising the learning process.

The 12-year-old age is one of the indicators of WHO's "Oral Global Goal for The Year 2020". The age of 12-years-old has become a highlight in caries experiments worldwide due to many areas with a high DMFT index, especially in developing countries. ${ }^{4}$ Children at this age are more receptive; thus, the more early a habit inculcated, the more impact will be applied in the long-term. ${ }^{5}$

The 12-year-old children have stepped on the fourth stage of the formal-operational stage. The stage of formal operational development is the child who is ahead or has stepped on adolescence. At this stage, the child can understand hypothesis and abstract principles. Children have been able to distinguish the difference between realistic and unrealistic things. ${ }^{6}$

Toothbrushing is one of the ways to prevent dental and oral diseases. Toothbrushing is the most effective way to remove the plaque mechanically. ${ }^{7}$ One of the most successful factors of toothbrushing is the toothbrushing technique. ${ }^{8}$ According to Wainwright ${ }^{9}$, among many toothbrushing methods, the most widely recommended toothbrushing technique by dental associations, toothbrush and toothpaste companies, and the textbooks, is the modified Bass method. ${ }^{9}$ This method is considered as the most effective method in removing plaque in the oral cavity. This method is more complicated than other techniques, thus recommended for adults; however, due to the technical complexity, it would be better to be taught at an early age, because it takes time and habituation to be able to understand this technique properly.

Media or visual aids in the educational process can determine educational success. Each tool has a different intensity. ${ }^{1}$ Along with the development of globalisation and technology, children nowadays are mostly engaged in technology such as audiovisual such as watching television, watching videos, playing gadgets, and other technology-based activities rather than spending time outdoors which mainly involves more physical activity and direct communication. Based on this event, the authors are interested in researching which media more effective to educate 12-year-old children regarding the proper toothbrushing technique nowadays. Is the audiovisual media education will be more effective than simulation media with a tooth model, or viceversa? The purpose of this study was to compare the effectiveness of audiovisual media in the form of animated film and simulation media in the form of a dental model on the students' toothbrushing skills.

\section{METHODS}

This research was a quasi-experimental study that tends analytic comparative. Oral and dental health education effectiveness parameters were evaluated through pre-test and post-test using a checklist form. Prior to the research, the researchers conducted a study regarding the most recommended toothbrushing techniques, then the authors creating scripts and storyboards based on the results. The type of video selected was an animated video that would befit the subjects in this study. The material provided directly by the presenters and the material presented through the means of video was precisely the same. The study inclusion criteria were male and female, aged 12-year-old, student of Ciganitri 2 State Elementary School, willing to follow the research, and had parental consent. The rest students who didn't fit these criteria were excluded.

This research was conducted on 40 students of Ciganitri 2 State Elementary School, aged 12 -year-old. Those 40 students will randomly be divided into two groups. The first group received education regarding the toothbrushing technique by the face-to-face method with dental model media. The second group received education of the toothbrushing technique with audio-visual media in the form of videos made by researchers.

At the beginning of the meeting, the introduction and a brief explanation about the purpose and procedure of this research were made. After the pre-test, the students were asked to brush their teeth and assessed by the research team by filling out the checklist form. Furthermore, both groups were educated once a week for four weeks. At the last meeting, researchers held a post-test with the same procedure with a pre-test.

The checklist form used 19 points that contained steps of brushing your teeth from the 
beginning, put the toothpaste, brushing each tooth region with modified Bass technique, and finally rinse. Calibration of the researcher team was needed and performed before conducting this study. The data obtained was calculated and analysed using SPSS software version 11.5. This research was approved by the Health Research Ethics Committee of Universitas Padjadjaran with registry number 115/UN6.C1.3.2/KEPK/PN2017. All respondents have been filled informed consent.

\section{RESULTS}

As much as 40 elementary students aged 12-yearold from Ciganitri 2 State Elementary School, with gender characteristics showed on Table 1.

Pre-test and post-test scores showed how students had mastered the toothbrushing skills.
The scores were obtained from the 19 points that must be taken at the time of the toothbrushing test, included steps to brush their teeth and brushing techniques in each region.

The value of the pre-test and post-test results in toothbrushing education in audiovisual groups of animated films and simulation model groups were varied. The values of the two groups can be seen in Table 2. The value of pre-test and post-test results in both groups were also varied, which presented in Table 3.

\begin{tabular}{ccccc} 
Table 1. Respondents characteristics based on gender \\
\hline Gender & $\begin{array}{c}\text { Audio visual } \\
\text { group }\end{array}$ & $\begin{array}{c}\text { Simulation } \\
\text { group }\end{array}$ & Total & $(\%)$ \\
\hline Male & 12 & 9 & 21 & 52 \\
Female & 8 & 11 & 19 & 47.5 \\
\hline Total & 20 & 20 & 40 & 100 \\
\hline
\end{tabular}

Table 2. Score of toothbrushing skill educated with audiovisual media in the form of animated film and simulation media in the form of a dental model

\begin{tabular}{|c|c|c|c|c|}
\hline \multirow{2}{*}{ Brushing skill checklist } & \multicolumn{2}{|c|}{ Audiovisual } & \multicolumn{2}{|c|}{ Simulation } \\
\hline & Pre-test (\%) & Post-test (\%) & Pre-test $(\%)$ & Post-test (\%) \\
\hline $\begin{array}{l}\text { Knows the best brushing time (morning after breakfast and } \\
\text { night before sleep) }\end{array}$ & 10.53 & 94.74 & 10.53 & 42.11 \\
\hline Placing toothpaste with the right amount and technique & 15.79 & 73.68 & 15.79 & 63.16 \\
\hline Brush left maxillary buccal posterior region & 5.26 & 52.63 & 15.79 & 63.16 \\
\hline Brush maxillary anterior region & 10.53 & 31.58 & 5.26 & 63.16 \\
\hline Brush right maxillary buccal posterior region & 10.53 & 89.47 & 5.26 & 89.47 \\
\hline Brush right maxillary palatal posterior region & 10.53 & 94.74 & 15.79 & 31.58 \\
\hline Brush palatal anterior region & 15.79 & 47.37 & 15.79 & 63.16 \\
\hline Brush left maxillary palatal posterior region & 10.53 & 94.74 & 15.79 & 36.84 \\
\hline Brush left mandibular buccal posterior region & 5.26 & 31.58 & 15.79 & 63.16 \\
\hline Brush mandibular labial anterior region & 21.05 & 26.32 & 15.79 & 57.89 \\
\hline Brush right mandibular buccal posterior region & 21.05 & 47.37 & 15.79 & 100.00 \\
\hline Brush right mandibular lingual posterior region & 10.53 & 78.95 & 10.53 & 89.47 \\
\hline Brush mandibular lingual anterior region & 10.53 & 57.89 & 5.26 & 100.00 \\
\hline Brush mandibular lingual posterior region & 15.79 & 21.05 & 10.53 & 63.16 \\
\hline Brush maxillary occlusal posterior region & 5.26 & 10.53 & 15.79 & 57.89 \\
\hline Brush mandibular occlusal posterior region & 10.53 & 47.37 & 15.79 & 26.32 \\
\hline Brush the tongue 1-3 times & 5.26 & 26.32 & 15.79 & 52.63 \\
\hline Rinse the mouth with water strongly and cleanly & w21.05 & 94.74 & 15.79 & 15.79 \\
\hline Brush in the right sequence & 21.05 & 31.58 & 21.05 & 63.16 \\
\hline
\end{tabular}

Data analysis was conducted to determine the effectivity of the method for improving the toothbrushing skills used in each group. The audiovisual group showed a $\mathrm{t}$-value of 6.79 with a $\mathrm{p}$-value $<0.05$, while the simulation group shows a $\mathrm{t}$-value of 8.38 with a $\mathrm{p}$-value $<0.05$.
These results indicated that there were significant differences in the students' toothbrushing skills before and after education with audiovisual media or simulation media. These results also mean that the audiovisual media of animated films and dental model simulation media 
Table 3. Pre-test and post-test audio-visual media in the form of animated film and simulation media in the form of a dental model

\begin{tabular}{cccc}
\multicolumn{2}{c}{ Audiovisual group } & \multicolumn{2}{c}{ Simulation model } \\
\hline Pre-test $(\%)$ & Post-test $(\%)$ & Pre-test $(\%)$ & Post-test $(\%)$ \\
\hline 12.37 & 57.11 & 11.60 & 61.05 \\
\hline
\end{tabular}

Table 4. Paired t-test of audiovisual media in the form of animated film group

\begin{tabular}{cccccccc}
\hline \multirow{2}{*}{ Paired sample test } & \multicolumn{3}{c}{ Paired differences } & & & & \\
\cline { 2 - 3 } & Mean & Std.dev & & & df & p-value & A \\
\hline Audiovisual group & 44.74 & 29.453 & 6.79 & 19 & 0.00000174 & 0.05 \\
\hline
\end{tabular}

Table 5. Paired t-test on simulation media in the form of a dental model

\begin{tabular}{cccccccc}
\hline \multirow{2}{*}{$\begin{array}{c}\text { Paired sample } \\
\text { test }\end{array}$} & \multicolumn{2}{c}{ Paired differences } & & t & p-value & A \\
\cline { 2 - 4 } & Mean & Std.dev & & & df & & \\
\hline Simulation group & 47.63 & 25.412 & 8.38 & 19 & 0.00000174 & 0.05 \\
\hline
\end{tabular}

Table 6. Independent t-test of audiovisual media in the form of animated film and simulation media in the form of a dental model

\begin{tabular}{lll}
\hline & M-difference & F-difference \\
\hline Mean & 47.63158 & 44.73684 \\
Std. dev. & 25.41247 & 29.45290 \\
$\mathrm{~N}$ & 20 & 20 \\
$\mathrm{df}$ & 38 & \\
Difference $\left(\mathrm{M}_{\text {diff }}\right.$ - $_{\text {- }}{ }_{\text {diff }}$ ) & 2.89474 & \\
Pooled variance & 756.63362 & \\
Standard error of difference & 8.69847 & \\
Hypothesized difference & 0.00002 & \\
t & 0.33 & \\
P-value (one-tailed) & 0.3706 & \\
P-value (two-tailed) & 0.7411 & \\
\hline
\end{tabular}

were both effective in changing the brushing skills of 12-year-old students in Ciganitri 2 State Elementary School. The statistical test used was a dependent t-test for each group (Table 4 and 5).

Differences of the pre-test and post-test value then tested statistically with a paired t-test (Table 6), which resulted in the p-value $>0,05$.

\section{DISCUSSION}

Results in Table 5 was consistent with the study conducted by Shah ${ }^{6}$ towards patients in a hospital which suggested that patients had a significant improvement in their knowledge after being given educational video. ${ }^{6}$ In other studies conducted by Janda ${ }^{10}$ also showed significant behavioural changes in the group of women who were given an educational video compared to a group who were not given any educational video. Video groups had become a routine in conducting preventive health activities. Heryoko ${ }^{3}$ and Albert ${ }^{11}$ stated the same result in their studies which found that groups with video education were significantly had higher scores than groups who studied conventionally. Audiovisual media is proven to be able to improve the ability to toothbrushing and other healthy behaviours. This result indicated that audiovisual media functions the senses of sight and hearing as well. The more senses used will make education easier to understand. ${ }^{13}$ According to Tuong ${ }^{12}$, audiovisual media that are often used to modify health behaviours effectively is the Video Modelling strategy. Video modelling is visually-demonstrated behaviour. This video modelling able to improve health self-care behaviour thus can be considered as a right intervention media.

The effectiveness of simulation media or artificial object in the form of a model can be seen 
in different studies. According to Lee ${ }^{13}$, the primary purpose of education with a model is to improve practical skills. Kong et $\mathrm{al}^{14}$ showed that 3DV (three-dimensional visualisation) and 3DP (threedimensional printing) models had the same effect on educational effectiveness compared to printed media. Simulation training with mannequins is widely used in medical education. Waikalul et $\mathrm{al}^{15}$ and Brodsky et $\mathrm{al}^{16}$ that discussed simulated objects for student and resident learning stated that both models are made to practice aspiration and injection skills. The result of the model is acceptable with satisfying results as a teaching model for simulation with affordable cost. An example of using mannequins as behavioural change can be found in the research of Gaca et al. ${ }^{17}$ In this study, the readiness of radiological residents for the treatment of anaphylaxis in pediatric patients in the radiology environment was observed and resulted that this type simulation is considered suitable for learning. ${ }^{17}$

Artificial object simulation media illustrates the original state, for example, in dental models. The tooth model can represent the state of the tooth and the surrounding tissue so that children can easily understand how to brush their teeth. The superiority of this artificial object can be seen in the Edgar Dale cone ${ }^{1}$, where the artificial object is ranked second best media. Also, the tooth model allows children to try and feel how to brush their teeth properly. The primary purpose of education with models is to improve practical skills. ${ }^{13}$ According to Montessori ${ }^{18}$, to develop thinking, a child needs objects that can be directly seen and heard. Children can develop through movement, for example, from the hands, and they need an object that can be worked on to create motivation for their activities.

Results in Table 6 showed that the t-value of 0.33 with a $p$-value $>0.05$ which means that both groups did not have significant differences. Based on the analysis, both media can be considered to having the same effectiveness. This result was similar to previous research conducted by Collins et $\mathrm{al}^{19}$, which performed the face-toface intervention and video in peripheral arterial disease patients, and the result statistically not showing significant differences. Partin et al ${ }^{20}$ also indicated the effectiveness of pamphlets as a printed media and video media was comparable in knowledge, preferences and behaviour of prostate cancer patients regarding their disease. Armstrong ${ }^{21}$, however, conducted a study which showed different results; learning by video was found to be more effective than learning through pamphlets in teaching knowledge and improving preventive health behaviours. This result probably indicated the differences in the control group and the specific strategies used.

Schulman ${ }^{2}$ suggested the use of various techniques to motivate, based on the assessment of individual needs, using appropriate educational aids, and repetition of orders for the purpose to be achieved. Education media is useful to stimulate the senses during the process of information delivery. Based on the Edgar Dale cone ${ }^{1}$, an artificial object, in this case, the tooth model, was ranked second after the original object. Movies, which included as audiovisual media, are ranked $8^{\text {th }}$, or $4^{\text {th }}$ from the lowest. ${ }^{1,2}$

In the present study, results that did not suit the Edgar Dale cone ${ }^{1}$, because audiovisual media in the form of animated film and simulation media in the form of tooth model have the same level of effectiveness. Along with the development of technology, plenty of audiovisual media produced. Consider that audiovisual media is easier to made and more comfortable to access lately. People are also far more familiar with audiovisual media through television, internet, and other means of electronic media. This condition may be a supporting factor of the success of audiovisual media as an effective medium thus can be reached equivalent effectiveness with the simulation media.

Audiovisual media should also be considered as an effective and convenient alternative learning media, and it is recommended the more frequent use. It is required to develop and enhance learning media that proper to educate children along with the growth of technology.

\section{CONCLUSION}

Audiovisual media and simulation media group intervention effectively improve toothbrushing skills. 


\section{REFERENCES}

1. Notoatmodjo S. Prinsip-Prinsip Dasar IImu Kesehatan Masyarakat. Jakarta: Rineka Cipta; 2003. p. 93,118.

2. Budiharto. Pengantar ilmu perilaku kesehatan dan pendidikan kesehatan gigi. Jakarta: EGC; 2010. p. 29, 85.

3. Haryoko S. Efektivitas pemanfaatan media audia visual sebagai alternatif optimalisasi model pembelajaran. J Edu Elekt. 2009; 5(1): 1-10.

4. Petersen PE. The World Oral Health Report 2003. Geneva: World Health Organization. 2003. p. 3-12.

5. Jurgensen N, Petersen PE. Promoting oral health of children through schools-Results from a WHO global survey 2012. Community Dent Health. 2013; 30(1): 204-18. DOI: 10.1922/CDH_3283Petersen15

6. Shah N, Mathur VP, Kathuria V, Gupta T. Effectiveness of an educational video in improving oral health knowledge in a hospital setting. Indian J Dent. 2016; 7(2): 70-5. DOI: 10.4103/0975-962X.184646

7. MCDonald RE, Avery DR, Dean JA. Dentistry for the Child and Adolescent. $8^{\text {th }}$ ed. New Delhi: Elsevier (A Division of Reed Elsevier India Pvt. Limited); 2004. p. 268.

8. Ali SA, Shahid R, Hussain M, Imran M, Khan M. Pattern of Oral Hygiene Maintenance among Patients Seen at Two Tertiary Hospitals. Pak Oral Dent J. 2015; 35(4): 645-8.

9. Wainwright J, Sheiham A. An analysis of methods of toothbrushing recommended by dental associations, toothpaste and toothbrush companies and in dental texts. Br Dent J. 2014; 217(3): E5. DOI: 10.1038/ sj.bdj.2014.651.

10. Janda M, Stanek C, Newman B, Obermair A, Trimmel M. Impact of videotaped information on frequency and confidence of breast selfexamination. Breast Cancer Res Treat. 2002; 73(1): 37-43. DOI: 10.1023/a:1015264103561

11. Albert NM, Buchsbaum R, Li J. Randomized study of the effect of video education on heart failure healthcare utilization, symptoms, and self-care behaviors. Patient Educ Couns. 2007; 69(1-3): 129-39. DOI: 10.1016/j. pec.2007.08.007.
12. Tuong W, Larsen ER, Armstrong AW. Videos to influence: a systematic review of effectiveness of videobased education in modifying health behaviors. J Behav Med. 2014; 37(2): 218-33. DOI: 10.1007/s10865-012-9480-7.

13. Lee IS, Lee YS, Park HJ, Lee H, Chae Y. Evaluation of phantom-based education system for acupuncture manipulation. PLoS One. 2015; 10(2): e0117992. DOI: 10.1371/ journal.pone.0117992.

14. Kong $\mathrm{X}$, Nie L, Zhang $\mathrm{H}$, Wang $\mathrm{Z}$, Ye Q, Tang L, et al. Do three-dimensional visualizationand three-dimensional printing improve hepatic segment anatomy teaching? A randomized controlled study. J Surg Educ. 2016; 73(2): 264-9. DOI: 10.1016/j.jsurg.2015.10.002.

15. Waikakul S, Vanadurongwan B, Chumtup W, Assawamongkolgul A, Chotivichit A, Rojanawanich V. A knee model for arthrocentesis simulation. J Med Assoc Thai. 2003; 86(3): 282-7.

16. Brodsky J, Patton E, Fischer HD. Arthrocentesis training using a knee simulation model. Osteoarthr Cartilage. 2013; 21: S151. DOI: 10.1016/j.joca.2013.02.32.

17. Gaca AM, Frush DP, Hohenhaus SM, Luo X, Ancarana A, Pickles A, et al. Enhancing pediatric safety:using simulation to assess radiology resident preparedness for anaphylaxis from intravenous contrast media. Radiology. 2007; 245(1): 236-44. DOI: $10.1148 /$ radiol.2451061381.

18. Rule AC, Welch G. Using object boxes to teach the form, function, and vocabulary of the parts of the human eye. Sci Activities Classroom Projects Curricul Ideas. 2008; 45(2): 13-22. DOI: $10.3200 /$ SATS.45.2.13-22.

19. Collins TC, Krueger PN, Kroll TL, Sharf BF. Face-to-face interaction compared with video watching on use of physical activity in peripheral arterial disease. A pilot trial. Angiology. 2009; 60(1): 21-30. DOI: 10.1177/0003319708318382.

20. Partin MR, Nelson D, Radosevich D, Nugent $S$, Flood $A B$, Dillon $N$, et al. Randomized trial examining the effect of two prostate cancer screening educational interventions on patient knowledge, preferences, and behaviors. J Gen Intern Med. 2004; 19(8): 835-42. DOI: 10.1111/j.1525-1497.2004.30047.x 
21. Armstrong AW, Idriss NZ, Kim RH. Effects of video-based, online education on behavioral and knowledge outcomes in sunscreen use:
A randomized controlled trial. Patient Educ Counsel. 2011; 83(2): 273-7. DOI: 10.1016/j. pec.2010.04.033 